\title{
Historia w kalendarzach polskich XVIII i początku XIX wieku. Literackie formy popularyzacji wiedzy o przeszlości
}

Maria Wichowa 


\section{Maria Wichowa}

\section{Historia w kalendarzach polskich XVIII i początku XIX wieku. Literackie formy popularyzacji wiedzy o przeszłości}

$\mathrm{K}$ alendarze dość często trafiają na warsztat badaczy, by wspomnieć studia Władysława Smoleńskiego ${ }^{1}$, pracę Stanisława Grzybowskiego ${ }^{2}$, książkę Bogdana Roka ${ }^{3}$, antologię Bronisława Baczki i Henryka Hinza ${ }^{4}$ czy liczne bibliografie publikacji kalendarzowych ${ }^{5}$. Zazwyczaj wypowiadali się o tej dziedzinie piśmiennictwa historycy, jednak jako źródło tekstów literatury popularnej może się ona okazać atrakcyjna także dla filologów.

Czytelnicy kalendarzy mogli zdobyć bądź pogłębić wiedzę o dziejach Polski i historii powszechnej. Najobszerniejszy wykład dziejów Polski pojawiał się w kalendarzu Stanisława Duńczewskiego, $\mathrm{w}$ różnych zresztą wariantach, w zależności od rocznika publikacji ${ }^{6}$. Autor wykładu, ukazującego się przez wiele lat, deklarował, zwracając się do czytelnika, że przyświeca mu cel dydaktyczny, utylitarny, chęć popularyzacji wiedzy. „Piękną, potrzebną i ciekawą rzecz rozumiejąc, ażeby każdy wiedział, co się w jego ojczyźnie działo od początków swoich aż do czasu teraźniejszego (...)", zgromadził w Geografiji polskiej informacje pochodzące z dzieł różnych historyków dla „zabawy”

I Zob. W. Smoleński, Kalendarze w' Polsce wieku XVIII, w: idem, Pisma historyczne, t. 1, Kraków 1901, s. 63-94; idem, Przewrót umystouy w Polsce wieku XVIII. Studia historyczne, opr. i wst. A. Wierzbicki, Warszawa 1979.

2 Zob. S. Grzybowski, Z dziejów popularyzacji nauki w' czasach saskich, Warszawa 1965 (Studia i Materiały z Dzicjów Nauki Polskiej, Seria A, z. 7), s. 111-173, rozdz. Kalendarze zamojskie.

3 Zob. B. Rok, Kalendarze polskie czasów saskich, Wrocław 1985 (Acta Universitatis Wratislaviensis 606, Historia 37).

4 Zob. Kalendarz pótstuletni 1750-1800, wyb., wst. i opr. B. Baczko, H. Hinz, Warszawa 1975; H. Hinz, Kalendarze z lat 1750-1800 jako pieru'sza masou a ksiqżka w Polsce, „Kultura i społcczcństwo”, R. 16, 1972, nr 1; H. Hinz, Kalendarze, w: Slownik literatury polskiego oświecenia, red. T. Kostkiewiczowa, Wrocław 1991, s. 200-205.

5 Zob. J. Jasiński, Wykaz czasopism i kalendarzy polskich na Warmii i Mazurach z lat 1718-1739, znajdujucych się w bibliotekach krajowych i zagranicznych, „Komunikaty Warmińsko-Mazurskic” 1961, nr 2; K. Kłodzińska, Katalog kalendarzy od XVI do XVIII w. w' zbiorach Biblioteki Kórnickiej, „Pamiçtnik Biblioteki Kórnickiej” 1963, z. 8; B. Górska, Katalog kalendarzy XVII-XVIII w zbiorach biblioteki Ossolineum, Wrocław 1968; H. Mącznik, Biblioteka polskich kalendarzy gospodarskich, ludowych i rolniczych od XVII wieku do 1980 roku, Puławy 1989.

6 Zob. S. Grzybowski, op. cit., s. 157. 
i pożytku czytelnika. Powstał więc wieloodcinkowy traktat historyczny, składający się z szeregu artykułów stanowiących osobne całości, wyczerpujące całość tematu. Dzieliły się one na Wiadomości, zwane czasem w późniejszych rocznikach Ciekawościami, odpowiadające na ogół dzisiejszym rozdziałom, a nieraz nawet przyjmujące postać osobnych rozprawek, te zaś składały się z mniejszych części zwanych Relacyjami. Dla przykładu wymienić można prace Duńczewskiego zamieszczone w Kontynuacyi geografiji Korony Polskiej iWielkiego Księstwa Litew skiego. Artykuły te informowały O królach $i$ książ̨tach $w$ chrześijańskiej wierze zostających (1776). Zamieszczono tam cykl Życie monarchów i królów polskich do utracenia korony przez Bolestawa Śmiatego opowiadające. Relacyja I nosi tytuł Królowie polscy od poczattu wiary katolickiej do utracenia korony. Autor zamieścił w tej części Geografiji... w porządku chronologicznym zwięzłe biogramy władców, poczynając od Mieszka I i „Bolesława I Chrobrym zwanego”. Wiadomości do swego wykładu czerpał z kompendium opracowanego w dobie mu współczesnej. Wyjaśniał:

Wiele historyj jest o królach polskich, ale doskonalszych i zupełniejszych nie masz, jako skompendyjowane [podkr. - M. W.] przez JWJMci księdza Władysława Łubieńskiego, teraźniejszego pisarza Wielkiego Księstwa, opata paradyskiego, którego tu naśladuję.

Idzie o dzieło Świat we wszystkich swoich częśiach większych i mniejszych, to jest: w Europie, Azyi, Afryce i Ameryce, w monarchijach, królestwach, księstwach, prowincyjach, wyspach i miastach, geograficznie, chronologicznie i historycznie okrestony, opisaniem religiji, rzqdów, rewolucyi, praw, zwyczajów, skarbów, ciekawości [podkr. - M. W.] igranickażdego kraju, z autorów francuskich, wtoskich, niemieckich i polskich zebranym, przyozdobiony..., wydane we Wrocławiu w roku 1740.

Zwraca uwage opinia Duńczewskiego o metodzie pracy Łubieńskiego. Było to kompendiowanie, a więc opracowanie podręcznego dzieła zawierającego zarys najważniejszych wiadomości o świecie, dokonane poprzez kompilację, stanowiące rodzaj wyciągu z wcześniej przestudiowanych ksiagg. Metoda ta była powszechnie stosowana w czasach saskich w pracach popularyzujących wiedzę naukową. Tak przygotował swój wykład historii Duńczewski, tak zorganizował warsztat pracy jego rówieśnik, ksiądz Benedykt Chmielowski, gromadząc materiał do własnej encyklopedii. Metodę swoją scharakteryzował we wstępnym zwrocie do czytelnika:

(...) kilkaset autorów od deszczki do deszczki przeczytawszy, tu i ówdzie pożyczając, to skupując, na ich fundamencie te Nowe dla ciebie, czytelniku, wystawiłem Aten $y$. Cokolwiek mądrego, ciekawego [podkr. - M. W.], do erudycyi służącego wyczerpnąłem, to sine invidia na theatrum moich Aten wystawiam curiosis $^{7}$.

Zatem zarówno Łubieński, jak i Chmielowski, a także Duńczewski i podobni mu „kalendarzowi historycy", trudniąc się popularyzacją wiedzy o przeszłości, stosowali od dawna znaną i wypróbowaną metodę poznania naukowego, na szeroką skalę stosowaną przez jednego z najbardziej znanych uczonych XVII wieku, jezuitę Atanazego Kirchera (1602-1680). Znawca barokowego encyklopedyzmu tak oto charakteryzował warsztat niemieckiego polihistora:

7 B. Chmielowski, Nowe Ateny albo akademia wszelkiej sciencyi petna..., wyb. i opr. M. i J.J. Lipscy, Kraków 1966, s. 17. 
Pisarz gotów jest przemierzyć wszystkie drogi i ścieżki przebyte już przez starożytnych i „nowożytnych”, obdarzony nienasyconą ciekawością i zapewne nie tak łatwowierny i bezbronny, jak to ukazywały schematyczne wizerunki, intelektualista zawsze doskonale poinformowany i dbający o zebranie możliwie najobszerniejszego materiału $(\ldots)^{8}$.

I encyklopedysta Chmielowski, i autorowie kalendarzy, opracowujący na ogół wieloodcinkowe traktaty historyczne do swoich periodyków, z powodzeniem opisaną metodę stosowali. Nie ma przesady czy nadużycia metodologicznego w zestawianiu Nowych Aten... z kalendarzami. Oba wydawnictwa miały na celu popularyzację wiedzy. Bogdan Rok uważa, że kalendarze należy uznać za swego rodzaju encyklopedię, wychodząca naprzeciw zapotrzebowaniu społeczeństwa ówczesnej Rzeczypospolitej ${ }^{9}$. Panował w nich duch encyklopedyzmu barokowego. Twórcyhistorycznych wykładów kalendarzowych przygotowywali dla czytelników rodzaj promptuarium (poradnika), stanowiącego źródło mądrości zarówno dla prostego szlachcica, jak i duchownego czy nawet polityka. Taka publikacja dawała im wszystkim gotową porcję wiedzy w dobrym gatunku, owoc bez pracy, aby mieli z czym wystąpić na publicznych mównicach, ambonach czy też sąsiedzkich dysputach. Uczeni-popularyzatorzy realizowali ambitny program oświecania umysłów, szerzenia wiedzy historycznej aktualnej, nowoczesnej, gdyż Duńczewski sięgał do kompendium cieszącego się uznaniem współczesnych, o czym świadczą liczne przedruki i skróty dzieła Eubieńskiego ${ }^{10}$. Autorzy traktatów kalendarzowych o tematyce historycznej gromadzili zawarte w studiowanych dzielach wiadomości, podając ich lokalizację i dobierając je pod kątem przydatności do „erudycyi”, a przy tym dbając o to, by były mądre i zaciekawiające. Wyrazy: „ciekawość”, „ciekawy”, „osobliwy”, "curiosa”, „mirabilia” przejawiają się raz po raz w dziełach naukowych baroku i czasów saskich, by wspomnieć choćby Gabriela Rzączyńskiego, pisarza o pokolenie starszego od Chmielowskiego i Duńczewskiego, badacza historii naturalnej, autora dzieła Historia naturalis curiosa (1721). Tytuły niektórych rozdziałów Nowych Aten... brzmią: Małego siviata wielkie cuda, to jest o ludziach mirabilia; Dalsze miranda o ludziach albo na postrach ludzi uczynione.

Nie dziwi więc informacja Duńczewskiego zawarta w Relacyi drugiej: Ksiqż̨̨ta Polskie po utraconej koronie aż do nabycia jej povtórnego o dokonaniach Bolesława Krzywoustego, któremu w zwycięstwach niebo pomagało:

Prusowie $z$ Pomeranami najechawszy księstwo mazowieckie, lubo porażeni będąc od Mazurów, Bolesław jednak za wodzem św. Anioła w dziecinnej postaci, w ręku złote jabłko trzymającego, poszedł pod Nakło, gdzie 40000 nieprzyjaciela trupem położył, a 2000 wziął w niewolę, i miasta poodbierał, i Świętopełkę starostą pomorskim uczynił, aby ich poskromił rebelizujących ${ }^{11}$.

8 C. Vasoli, Encyklopedyzm w XVII wieku, tł. A. Anuszkicwicz, Warszawa 1989 (Studia z historii filozofii i idei, t. 4), s. 29.

9 Zob. B. Rok, op. cit., s. 126.

${ }_{10}$ T. 1, wyd. Wrocław 1740, osobno fragm.: Wiadomości podczas interregnum wybrane z ksiegi „Swiat we wszystkich swoich częściach okryslony”, Wilno 1763; Historyja z opisaniem rządów i urzędów polskich... Na cztery części podzielona a na żadanie wielu przedrukowana, wyd. F. Paprocki, Wilno 1763; wyd. n.: Wilno 1771.

1 S. Duńczewski, Kontynuacyja geografiji Korony Polskiej i Wielkiego Księstwa Litewskiego, 1756 (Relacyja II). 
Zamojski profesor oprócz faktów historycznych nastawia się na zaprezentowanie różnego typu osobliwości, bo to ciekawi czytelnika jego wykładu. Dociekliwość badacza kieruje się często ku temu, co najrzadsze w świecie, najbardziej osobliwe, zagadkowe, zadziwiające, niezwykłe. Autor Kalendarza Gospodarskiego na R. P. 1804 podaje szereg informacji o mirabiliach, bynajmniej nie wyssanych z palca, popartych poważnymi autorytetami:

Małgorzata, żona hrabi Wierzbosława, w Krakowskiem, jednym razem 36 synów powiła, o czym pisze Kromer, Długosz, Bielski, Paprocki, dnia 21 Ianuarii roku pańskiego 1269.

Tu nie ma co polemizować z podanymi faktami, po prostu czytelnik kalendarza powinien uwierzyć autorowi i tę osobliwość rozgłaszać dalej. Wracając do poprzedniego cytatu, trzeba uznać, że aby zwycięstwo księcia mieściło się w racjonalnych granicach, ten musiał otrzymać pomoc nadprzyrodzoną, i nie należy tego kwestionować. Podobnie relacja historyczna jest budowana w Nowych Atenach...:

Kaeta, miasto z znaczną w neapoliańskim królestwie fortecą alias z dwoma zamkami i dwoma kasztelami nad portem, łacinnicy go zwą Cajeta. Prezentują tu skałę nad morzem, która się (powiadają) rozpadła podczas śmierci Zbawiciela świata. Niewiernik jeden, gdy w szparę tę wsadził rękę, od skały wnet stulonej jest ucięta to i tam się konserwuje ${ }^{12}$.

W przytoczonym cytacie zawarte są dwa rodzaje informacji. Po pierwsze, z troską o czytelnika, być może przyszłego peregrynanta, podano podstawowe wiadomości o położeniu geograficznym Gaety, o zabytkach, przekazano także lacińską nazwę miejscowości, po drugie pojawiają się mirabilia. W tym wypadku trudno powołać się na źródła, raczej na tradycję. Wyraz „powiadają” oznacza także pewien dystans narratora do przedstawionych wydarzeń. Tutaj poznanie rozumowe dochodzi już do granic możliwości, badacz wkracza na teren historii świętej, a racjonalista ograniczony jest przez teologa:

Z punktu widzenia teologii nie ma więc wyraźnej przerwy między tym, co możliwe, a tym, co niemożliwe, pomijając cud wyraźnie rozpoznawany jako bezpośrednia interwencja Boga. Wszystko się może zdarzyć czy powstać; rzeczywistość stale prześciga fikcję ${ }^{13}$.

Granica między tym, co jest możliwe, a tym, co niemożliwe, nie jest wyraźnie przez Chmielowskiego nakreślona. Oblicze intelektualne polskiego popularyzatora nauki ma wiele wspólnego z kulturą baroku. Podobnie rozumował Lodovico Moscardo, twórca wspaniałego zbioru muzealnego oraz katalogu, w którym ów zbiór opisał. Kolekcjonował również kamienie

12 B. Chmiclowski, op. cit., s. 409.

${ }^{13}$ Cyt. za: K. Pomian, Zbieracze i osobliwości. Paryż, Wenecja XVI-XVIII wieku, tł. A. Pieńkos, Warszawa 1996, s. 100. 
przywiezione z Ziemi Świętej, na przykład z miejsca, w którym wznosił się Krzyż Zbawiciela. Wyliczanie kamieni zamyka się słowami:

Kończę opisywanie kamieni z Ziemi Świętej kamieniem znajdującym się w tym muzeum, wyjętym z jeziora Garda pod zamkiem Sirmion w diecezji Werony. Kamień ów otwiera się na dwie części. Wjednej widzimy krzyż zrobiony przez naturę, tak jakby go zrobił jakiś pomysłowy rzeźbiarz: składa się on $z$ dwóch skrzyżowanych okragłych drzewc, zastygłych w kamieniu. Można przypuszczać, iż Bóg pozostawił nawet w masie gór pamięć przeświętej Męki, jaką przyjął za rodzaj ludzki ${ }^{14}$.

Krzyż ten, w istocie rzeczy eksponat pochodzący ze świata minerałów, jest zarazem eksponatem nawiązującym do historii świętej.

Granica między zjawiskiem przyrodniczym a tym, co nadprzyrodzone, ulega w ten sposób zniesieniu, jako że to pierwsze może być naznaczone tym drugim, a wytwory natury jawią się jako zdolne do przybierania wszelkich wyobrażalnych form i odznaczania się wszelkimi cechami, ponieważ zależą od nadprzyrodzonych znaczeń, w które mogą zostać wyposażone ${ }^{15}$.

Identyczny punkt widzenia prezentował wojewoda miński, KrzysztofZawisza (1666-1721) podczas swojej peregrynacjipo Włoszech. Zostawił po sobie interesujące pamiętniki. Podczas „zwiedzania” pilnie zwracał uwage na raritates et currositates (tak brzmi tytuł jednego z „podrozdziałów” jego zapisków). Oglądając Wenecję, szczególnie interesował się osobliwościami w oglądanych obiektach. Widać uderzające podobieństwo jego relacji z obserwacjami zarówno Moscarda, jak i Chmielowskiego:

Kościół i klasztor benedyktynów na wyspie, bardzo wspaniały i piękny, z perspektywami na morze. Refektarz dziwnie piękny i wielki, w miniaturach wszystek. Ołtarz marmurowy, słup u niego marmurowy, na którym naturalnych żył kilka figury różne pokazujących, jako to: na krzyżu Pana Jezusa jakby umyślnie robionego, gruszek dwie i ludzka głowa. Figurki te małe: Pan Jezus na krzyżu jako na dłoń długi, gruszka niewielka, głowa jak talar ${ }^{16}$.

Ten sam rodzaj wyobraźni, ciekawości, zainteresowań, dociekliwości naukowej wykazują twórcy artykułów kalendarzowych o tematyce historycznej. W podobny sposób jak historia świecka relacjonowane są dzieje Kościoła, to znaczy w formie systematycznie prowadzonego wykładu. Stosunkowo niewiele miejsca zajmuje hagiografia, której nadano różne formy wypowiedzi — od zwięzłych biogramów ujętych prozą, opracowywanych na podstawie popularnych żywotów świętych, krążących w obiegu czytelniczym (choćby zbioru Skargi czy Jaroszewicza), po wierszowane poematy o świętych patronach na poszczególne dni w roku. Takie materiały

\footnotetext{
14 Ibidem.

15 Ibidem.

16 K. Zawisza, Pamiętniki, opr. J. Bartoszewicz, Warszawa 1862, s. 81.
} 
pojawiły się w licznych kalendarzach ogólnych. W kalendarzach jezuickich drukowano też specjalne modlitwy do patronów miesięcznych; w Kalendarzu politycznym jezuitów lubelskich z roku 1734 zamieszczono modlitwy do świętych męczenników, poprzedzane krótkimi ich biogramami prozą (tak na przykład patronem stycznia jest św. Sebastian).

Na tle owej szarzyzny i monotonii piśmiennictwa żywotopisarskiego pojawiają się także bardziej interesujące utwory literackie. Na uwagę zasługuje na przykład poemat hagiograficzny, wydrukowany w Kalendarzu Michałowskiego z 1736 roku $^{17}$, niepodpisany nazwiskiem autora. W spisanych w nim wierszem żywotach świętych polskich, opartych na dziełach Skargi, Baroniusza, Michała A. Gorczyńskiego, a nawet na Kronice Miechowity, łączą się fakty historyczne z legendą hagiograficzną. Jest to udana próba popularyzowania sylwetek świętych dopiero co wyniesionych na ołtarze oraz ożywienia kultu świętych popadających w zapomnienie, jak choćby Jana Kantego, którego sylwetkę autor nakreślił w poemacie bardzo wyraziście, ubolewając, że kanonizacja profesora Akademii Krakowskiej „leniwo idzie”, ale przysporzy większej chwały przyszłemu świętemu:

Bo cudów teraz świeżych dość wynotowały

Pisarzów pióra, by się do procesu zdały.

Jak wiadomo, do kanonizacji Jana Kantego doszło w roku 1767.

W omawianym dziełku dostrzec można popieranie kultu świętych miejscowych. Spośród dwunastu „patronów i przed Bogiem obrońców Królestwa Polskiego”, opiewanych w poemacie, sześciu z nich to błogosławieni mężowie, dzięki którym stulecie piętnaste zwane było „felix saeculum Cracoviae”. Byli to: Izajasz Boner, Jan Kanty, Michał Giedrojć, Świętosław zwany Milczącym, Szymon z Lipnicy i Stanisław Kazimierczyk. Tradycja krakowska łączyła ich węzłem przyjaźni i zażyłości. Pierwszy wykaz świątobliwych kapłanów „wieku szczęśliwego w Krakowie” podał Jan z Trzciany w biogramie Michała Giedrojcia w roku 1544. Opowieść o „złotym wieku” Krakowa przekazaną przez Baroniusza w żywocie Izajasza tak upowszechniono, że dotarła do żywotów świętych pisanych przez innych autorów, stała się także tematem licznych poematów hagiograficznych, a nawet obrazów.

Piśmiennictwo hagiograficzne, zgodnie ze swoim założeniem ideowym, podawało w kalendarzach wzorce osobowe do naśladowania albo przynajmniej do rozpamiętywania, z wyraźną tendencją dydaktyczną. Na ogół nauka moralna tych utworów pozostawała w kręgu myślenia potocznego. Bliska hagiografii jest biografistyka. W kalendarzu Duńczewskiego na rok 1760 zamieszczono Relacyje o kardynatach i ksiażęciu prymasie, arcybiskupie gnieźnieńskim. Jest to rodzaj zwięzłego katalogu biskupów, a więc forma wypowiedzi znana od dawna, choćby z twórczości Długosza.

Osobna grupa tekstów kalendarzowych, w których pojawiła się tematyka historyczna, to panegiryki, czasem ukryte w wierszowanych listach dedykacyjnych. Interesującym przykładem kalendarzowej literatury panegirycznej jest wiersz z kalendarza Michałowskiego z 1736 roku, dedykowany Izabeli z Humieckich Małachowskiej, wynoszący zasługi dla ojczyzny świetnego rodu Humieckich herbu Junosza. Naturalnie, w takich wypadkach chętnie przypominano legendy herbowe, na przykład

17 Zob. Kalendarz Polski i Ruski, w którym święta roczne i biegi niebieskie, aspekty, wybory, czas siania, szczepienia... wschód i zachód storica... na Rok Pariski 1736... przez M. Ignacego Pawła Michatouskiego, Kraków, Druk. Akademicka. 
w kalendarzach Duńczewskiego opiewano świetność rodu Zamoyskich, szczególnie jego starożytne pochodzenie: fakt, że pierwszy Jelitczyk przyszedł do Polski w roku $550 \mathrm{w}$ drużynie Lecha, następnie postać (jak dziś wiadomo legendarną) Floriana Szarego, sławnego rycerza tego rodu, rannego w bitwie pod Płowcami. Część tych heraldycznych rewelacji przeniknęła do herbarza Duńczewskiego.

$\mathrm{Z}$ panegiryków wyłaniały się często wizerunki postaci chwalonych tak bardzo (z oczywistą przesadą), że stanowiły wzorce osobowe do naśladowania, jak w wierszu zamieszczonym w kalendarzu Michałowskiego z 1718 roku, dedykowanym staroście opoczyńskiemu, Aleksandrowi Wielopolskiemu. Autor pochwały nie ukrywa, że oczekuje od obdarowanego wierszem stosownej gratyfikacji. Utwór jest mierny pod względem artystycznym, zawiera pompatyczne pochwały Wielopolskiego, wyszukane, lecz w złym guście przenośnie, alegorie, amplifikacje. Panegiryk stawał się więc w kalendarzach metodą kształtowania opinii publicznej.

Panegiryki zawierały zatem okruchy informacji również o historii właśnie „dziejącej się”, współczesnej dacie druku kalendarza. Podobnie reagowała kolęda, gatunek kalendarzowy zawierający życzenie na Nowy Rok, na przykład Kolęda Warszawska na 1795 rok:

By krwawe wojny ustały,

Trąby pokoju zabrzmiały,

By dzieci rosły w te cnoty,

Które składały wiek złoty (...)

Żołnierz niech nie drze, nie huczy, rabuje.

Wyraźne są tu echa wydarzeń współczesnych; życzenia składane na Nowy Rok zawierają intencje, aby rodakom żyło się lepiej, aby czas wojny się skończył. Ten typ kolędy był w dobie staropolskiej bardzo popularny, by podać jako przykład Kolędę na Nowe Lato Jana Kochanowskiego.

Wyraz „kolęda” w kalendarzach występował jeszcze w jednym znaczeniu: „książka-podarunek na Nowy Rok", o czym świadczy Kolęda Warszawska, wydawana przez Antoniego Wiśniewskiego od 1752 roku, a przeobrażona w roku 1788 w Kalendarzyk Polityczny, zawierający bardzo postępowy program, informujący o odkryciach, wynalazkach, propagujący osiągnięcia ówczesnej nauki. Kolęda... podawała szereg najróżniejszych wiadomości o sprawach bieżących krajowych i zagranicznych, informacje o badaniach z zakresu fizyki, astronomii i tym podobne. Zawierała także publicystyczne formy wypowiedzi, na przykład artykuły prasowe.

Kolejny gatunek piśmiennictwa historycznego występujący w kalendarzach to typowa epika historyczna, na przykład poemat Opisanie wierszem klęski Turków pod Wiedniem i Parkanami ${ }^{18}$, forma popularyzacji historii atrakcyjniejsza aniżeli tradycyjny wykład.

Pojawiały się także legendy historyczne, na przykład w Kalendarzu Duńczewskiego na rok 1749 $\mathrm{w}$ dziale Raritates polskie, W. Ks. Litewskiego i prowincyi do nichże należących przeczytać można legendę o bazyliszku znalezionym w jednej z piwnic warszawskich w 1584 roku.

18 Zob. S. J. Niewieski, Kalendarze roczne od 1672 r. do 1700 (kalendarz na r. 1685); przedr.: J. E. Minasowicz, Zbiór rytmów polskich, cz. 4, Warszawa 1756. 
W ramach popularyzacji nauki posługiwano się w kalendarzach formą „wykładów monograficznych". Tak więc Duńczewski ogłosił w roku 1747 traktat o monecie Wiadomości o monecie polskiej i cudzoziemskiej, do różnych transakcyi sq̨dowych tak duchowych, jako i swieckich etc. od starożytności aż do czasu teraźniejszego i lat następujących wiedzieć potrzebna. $Z$ redukcyją staropolskich pieniędzy na teraźniejszq monety kurrencyję od poczq̨tku ojczyzny naszej, zażywanie $w$ niej pieniędzy aż do roku 1746 opisana. Dziełko obejmuje 20 kart druku. Ukazało się także w formie osobnej książeczki. Ponownie zostało zamieszczone w kalendarzu na rok 1755, w wersji rozszerzonej w stosunku do redakcji z roku 1747.

Popularnym gatunkiem wypowiedzi kalendarzowej była chronologia, zwana niekiedy diariuszem. W kalendarzu Duńczewskiego na rok 1755 zamieszczono Dyjaryjusz stawniejszych dziejów polskich $z$ kronik autorów poważnych. Jest to rodzaj wypisów z dzieł historyków, takich jak Kadłubka, Długosza, Bielskiego czy Kromera, zestawienie bardzo krótkich informacji o ważnych wydarzeniach historycznych, ułożonych w porządku chronologicznym. Podobniejsze do diariusza jest kalendarium, określane według dzisiejszej terminologii, zaś w badanych periodykach występujące pod nazwą Chronologija polska. W Kalendarzu Gospodarskim na r. 1809 nosi podtytuł Krótko zebrana z osobliwych $z$ darzeń $i$ szczególnych przypadków. Informacje tam zawarte są niesłychanie zwięzłe, zazwyczaj podawana jest przy nich lokalizacja źródla wiadomości, a na końcu data wydarzenia, na przykład:

Władysław Jagiełło, król polski, Krzyżaków, których było 140 tysięcy, zbił pod Grunwaldą. 50 tysięcy na placu i plejzerowanych było, 40 tysięcy wziął w niewolą, choragwi 51. Mistrz sam Krzyżaków na placu poległ. Krom[er], lib [er] 16 (...) 1410.

Notatki sporządzane były w porządku chronologicznym. Czasem także kalendarium układano w formie tabeli. Nieraz występowała synonimicznie nazwa Rewolucyje roczne.

Kalendarz byl zatem środkiem komunikacji społecznej, trybuną, z której głoszono spopularyzowaną wiedzę historyczną. Wykazuje on podobieństwo do sylw, które istotnie zawierały las rzeczy (silva rerum). Tak więc autorzy owych ksiąg zamieszczali teksty literackie obok porad praktycznych, mów sejmowych, pamfletów, odpisy nowin, anegdoty, niecenzuralne fraszki, a także wiersze polityczne, okolicznościowe, odpisy dokumentów i tym podobne ${ }^{19}$. Kalendarz to swego rodzaju drukowana sylwa, opracowywana corocznie, prezentująca myślenie potoczne. To także medium, środek przekazu kształtujący opinię publiczną, gusty czytelnicze, w tym i upodobania literackie, ale zarazem wychodzący naprzeciw oczekiwaniom przeciętnego odbiorcy.

Gdy idzie o popularyzację historii, dawne polskie kalendarze bardzo się zasłużyły. Zamieszczone w nich wykłady o dziejach państwa i narodu mają dużą wartość. Opracowywali je intelektualiści dobrze przygotowani do pracy naukowej, popularyzacja wiedzy historycznej przebiegała programowo, według właściwie przemyślanej i długofalowo realizowanej koncepcji, przy użyciu odpowiednio zastosowanych literackich form wypowiedzi.

19 Zob. K. Maliszewski, Problem badań nad dziejami komunikacji spotecznej w dobie nowożytnej na przүkładzie polskich gazet rękopismiennych XVII-XVIII w., w: Między barokiem a oświeceniem. Nou'e spojrzenie na czasy saskie, red. K. Stasiewicz, S. Achremczyk, Olsztyn 1996, s. 198. 